\title{
Toleransi Berdasarkan Cerita Rakyat Tallu To Sala' Dadi di Toraja
}

\author{
Marsi Bombongan Rantesalu, ${ }^{1}$ Iswanto ${ }^{2}$ \\ ${ }^{1}$ Sekolah Tinggi Agama Kristen Negeri Kupang \\ marsibombongan@gmail.com \\ ${ }^{2}$ Sekolah Tinggi Agama Kristen Negeri Kupang \\ iswantoyohanes@rocketmail.com
}

\begin{abstract}
Tolerance is described as a concept of cultural phenomena that are integrated through religious life. Conflict as an internal problem while the challenges of the times (globalization) are goals that must be answered through a spirit of tolerance. The concept that will be analyzed is based on folklore tallu to sala 'dadi in Toraja. This study intends to examine the structure of the tallu to sala 'dadi story, and the tolerance value contained in the story. The theory used in this study is the semiotic social theory. While the method used is a qualitative method of content analysis and hermeneutic methods. As a result, data was obtained that the story was of a novel type, which revealed the struggles of human life in living everyday life. The values of tolerance contained include the value of acceptability and understanding that are paired with togetherness and complementarity. Based on these findings, it can be defined that tolerance is the attitude of accepting and understanding shortcomings and differences through togetherness and complementarity.
\end{abstract}

Keywords: tolerance, toraja society, tallu to sala' dadi

Abstrak: Toleransi dideskripsikan sebagai konsep fenomena budaya yang terintegriasi melalui kehidupan beragama. Konflik sebagai masalah internal sedangkan tantangan jaman (globalisasi) merupakan tujuan yang harus dijawab melalui semangat toleransi. Konsep itulah yang akan dianalisa berdasarkan cerita rakyat tallu to sala' dadi di Toraja. Penelitian ini bermaksud mengkaji struktur ceritera tallu to sala' dadi, dan nilai toleransi yang terkandung dalam ceritera tersebut. Teori yang digunakan dalam penelitian ini ialah teori semiotik sosial. Sedangkan metode yang digunakan ialah metode kualitatif analisis kontent serta metode hermeneutik. Hasilnya, diperoleh data bahwa cerita tersebut berjenis novel, yang mengungkapkan pergumulan hidup manusia dalam menjalani hidup sehari-hari. Adapun nilai-nilai toleransi yang terkandung meliputi nilai keberterimaan dan kesepahaman yang dipadankan dengan kebersamaan dan saling melengkapi. Berdasarkan temuan tersebut dapat di definisikan bahwa toleransi adalah sikap menerima dan memahami kekurangan dan perbedaan melalui kebersamaan dan sikap saling melengkapi.

Kata-kata kunci: toleransi, masyarakat Toraja, tallu to sala' dadi

\section{A. Pendahuluan}

Toleransi merupakan salah satu penciri globalisasi. Sebelum abad ke-5 toleransi didefinisikan sebagai ketahanan dalam menghadapi penderitaan dan rasa 
sakit. Definisi ini bergeser menjadi kemampuan bertahan atau menanggung suatu keadaan atau kondisi tertentu. Definisi ini diambil dari bahasa Perancis tolerance. Lebih lanjut, pada 1765 makna toleransi bergeser menjadi menerima berbagai perbedaan.

Konsep toleransi di Indonesia dimaknai sebagai sikap saling menghormati dan menghargai antar kelompok atau antar individu. Sikap toleran diyakini dapat mencegah terjadinya diskriminasi dalam masyarakat. Sebagai bahan kajian, penelitian menggunakan cerita rakyat to sala' dadi dalam masyarakat Toraja.

Populasi orang Toraja diperkirakan sekitar satu juta jiwa, dengan lima ratus jiwa tinggal di Kabupaten Tana Toraja, Kabupaten Toraja Utara, dan Kabupaten Mamasa. Mayoritas orang Toraja memeluk agama Kristen, yang lain beragama Islam dan Aluk To Dolo. Sensus BPS Kabupaten Tana Toraja tahun 2015 menunjukan bahwa mayoritas penduduk menganut agama Kristen Protestan sebanyak 72.54\%, kemudian Katolik 17.57\%, Islam 8.43\%, Hindu 1.07\%, dan Buddha 0.39\%.

Tana Toraja akrab dengan sebutan tondok lepongan bulan tana matari allo (harfiah: negeri yang bulat seperti bulan dan matahari). Nama ini mengandung makna persekutuan berbagai wilayah adat. Inilah yang menyebabkan Tana Toraja tidak pernah diperintah oleh seorang penguasa tunggal, masing-masing wilayah diperintah oleh pemangku adat. Karena perserikatan dan kesatuan kelompok adat tersebut, maka diberilah nama perserikatan bundar (bulat) yang terikat dalam suatu pandangan hidup dan keyakinan sebagai pengikat seluruh daerah dan kelompok adat orang Toraja.

Dengan demikian, artikel ini akan membahas masalah toleransi berdasarkan ceritera rakyat tallu to sala' dadi di Toraja. Tujuan penelitian dibagi menjadi dua yaitu (1) Struktur ceritera rakyat tallu to sala' dadi, dan (2) Nilai toleransi dalam ceritera Rakyat tallu to sala' dadi.

Untuk menjawab tujuan penulisan, maka penelitian ini menggunakan metode kualitatif analisis kontent, yaitu sebuah metode pengumpulan data berupa kata-kata, kalimat, gambar, dan bukan angka-angka dengan beberapa pertimbangan yaitu, pertama, analisis didasarkan atas deskripsi permasalahan secara keseluruhan. Kedua, deskripsi yang dimaksudkan dilanjutkan dengan analisis sehingga pada akhirnya menghasilkan suatu simpulan. Sejalan dengan itu, di sini digunakan juga metode hermeneutik. Hermeneutik adalah teori tentang bekerjanya pemahaman dalam menafsirkan teks. ${ }^{1}$ Hermeneutik dalam penelitian ini dipahami dalam pengertian berisikan perbincangan teoritis tentang the conditions of possibility sebuah penafsiran, menyangkut hal-hal apa yang dibutuhkan atau prosedur bagaimana yang mengejawantah dari sebuah teks sampai kepada makna-makna yang harus dipenuhi untuk menghindari pemahaman yang keliru terhadap teks. Oleh karena itu, hermeneutik dalam pengertian ini mengandaikan adanya kebenaran di balik teks dan untuk menyingkap kebenaran tersebut.

Tugas hermeneutik adalah memahami teks lebih baik dari pengarangnya sendiri, dan memahami pengarang teks lebih baik dari pada memahami diri sendiri. Jadi metode hermeneutik akan mencoba menggali, dan memahami faktor dalam teks. Tugas hermeneutik membawa keluar makna internal suatu teks, serta situasinya menurut zamannya. Hermeneutik berhubungan dengan interpretasi yang mencoba melihat teks baik dari aspek dari luar maupun aspek dari dalam untuk memahami

${ }^{1}$ Paul Ricoeur, Hermeneutics and the Human Science: Essay on Language, Action, and Interpretation (Cambrigde: Cambridge University Press, 1981), 43. 
makna yang terkandung di dalamnya. ${ }^{2}$ Dikaitkan dengan fungsi utama hermeneutik sebagai metode untuk memahami agama, maka metode hermeneutik dianggap tepat untuk memahami karya sastra. Dengan pertimbangan bahwa di antara karya tulis, yang paling dekat dengan agama adalah karya sastra. ${ }^{3}$

Metode hermeneutik mengunakan pendekatan secara abduksi, yaitu proses mendekati data (dalam hal ini teks atau tanda-tanda lain) melalui berbagai asumsi dan kemungkinan sehingga muncul sekian wajah kebenaran. Proses ini sering disebut sebagai proses hermeneutical circle, yaitu proses dinamis dalam menafsirkan teks atau tanda-tanda berdasarkan asumsi-asumsi, pengalaman serta terjadinya saling menafsirkan antara sesama teks atas teks yang kemudian melahirkan jaringan dan lingkaran interteks. Dengan metode hermeneutik, peneliti mencoba mengerti dan menafsirkan fungsi dan makna yang terkandung dalam cerita rakyat.

Pemahaman dan interpretasi teks terhadap cerita rakyat dilakukan secara terus menerus, karena pada dasarnya interpretasi dalam teks sastra bukanlah merupakan interpretasi yang bersifat definitif, karena interpretasi terhadap teks itu sebenarnya tidak pernah tuntas dan selesai. Dengan demikian, setiap teks sastra senantiasa terbuka untuk diinterpretasi terus-menerus. Proses pemahaman dan interpretasi teks bukanlah merupakan suatu upaya menghidupkan kembali atau reproduksi, melainkan upaya rekreatif dan produktif. Penleliti dengan konsekuensinya berperan penting dalam pemberian makna.

\section{B. Semiotika Sosial Dalam Cerita Rakyat}

\section{Fungsi dan Makna Cerita Rakyat}

Cerita Rakyat Masyarakat Toraja (CRMT) ditelusuri fungsi dan maknanya dengan mengggunakan teori semiotik sosial yang dikemukakan oleh Halliday. Hal ini sejalan dengan pendapat Finegan yang menyatakan bahwa sastra lisan memiliki berbagai peristiwa sosial dan kebudayaan yang terjadi di masyarakatnya. ${ }^{4}$ Oleh karena itu, pembicaraan mengenai CRMT tidak selesai pada tataran strukturnya saja, tetapi harus memperhatikan konteks sosial untuk mendapatkan fungsi dan makna yang terkandung di dalamnya.

Analisis fungsi dan makna dalam penelitian ini berangkat dari sistem tanda yang dengan sendirinya memanfaatkan teori-teori semiotika. Teori semiotika sendiri, khususnya semiotika sosial didukung oleh teori-teori sosiologi sastra. Argumentasi dalam teori semiotika adalah karya sastra adalah proses komunikasi yang dapat dipahami semata-mata dalam kaitannya antara pengirim dan penerima. Makna tanda-tanda bukanlah miliknya sendiri, tetapi berasal dari konteks di mana ia diciptakan, di mana ia tertanam. Jadi sebuah tanda bisa memiliki arti sangat banyak atau sama sekali tidak berarti. ${ }^{5}$

Berkaitan dengan konsep 'semiotik' yang berasal dari konsep tanda, Halliday berpandangan bahwa konsep 'semiotik' yang ada selama ini konsep yang sempit karena tanda selalu cenderung dilihat sebagai sesuatu yang terpisah, sesuatu yang mandiri, yang terutama berdiri sendiri sepenuhnya sebelum dihubungkan dengan tanda-tanda lain. Halliday mengubah batasan semiotik bukan sebagai kajian tentang

2E. Sumaryono, Hermeneutik Sebuah Metode Filsafat (Yogyakarta: Kanisius. 1993), 35-59

3 I Nyoman Kutha Ratna, Teori, Metode, dan Teknik Penelitian Sastra (Yogyakarta: Pustaka Pelajar, 2004), 46.

${ }^{4}$ Ruth Finegan, Oral Tradition and Verbal Arts (London: Chapman and Hal, 1979), 3

${ }^{5}$ Ratna, Teori, Metode dan Teknik, 117. 
tanda, tetapi kajian tentang sistem tanda. Dengan demikian ilmu bahasa adalah kajian tentang makna. ${ }^{6}$

Halliday berpandangan bahwa bahasa merupakan bagian dari sistem tanda (semiotik) yang merupakan aspek untuk mempelajari makna. ${ }^{7}$ Bahasa sebagai salah satu dari sejumlah sistem makna yang secara bersama-sama, membentuk budaya manusia. Bahasa digunakan dalam konteks, tempat orang-orang berada dalam suatu wacana ketika mereka menggunakan bahasa dapat berkomunikasi karena memahami teks.

Bahasa berhubungan erat dengan budaya dan masyarakatnya tempat dia tinggal. Bahasa merupakan alat sekaligus pengungkap kebudayaan termasuk di dalamnya cabang-cabang seni seperti sastra. Bahasa memiliki peran dan fungsi penting dalam kehidupan manusia yang berbudaya, dengan demikian, berarti bahwa setiap ragam kebudayaan suku bangsa memiliki sistem bahasa sendiri. Wacana dalam pandangan Halliday adalah bahasa (baik lisan maupun tulis) yang sedang melakukan pekerjaan di dalam suatu konteks situasi dan kultural. ${ }^{8}$

Halliday menyamakan sistem sosial dengan kebudayaan. Istilah sosial untuk mengemukakan dua hal secara bersamaan. Ia menyebut bahasa sebagai 'semiotika sosial'. Istilah semiotik merujuk pada sistem tanda bukan hanya tanda-tanda.

Pandangan Halliday yang pertama adalah bahasa sebagai semiotik sosial. Hal ini berarti bahwa bentuk-bentuk bahasa mengodekan (encode) representasi dunia yang dikonstruksikan secara social. Semiotik sosial melihat teks dari 'segi prosesnya' sebagai peristiwa timbal balik, suatu pertukaran; dan bentuk teks paling dasar adalah percakapan lebih penting dibandingkan dengan jenis-jenis lainnya. ${ }^{9}$ Teks adalah hasil lingkungannya, hasil suatu proses pemilihan makna yang terus menerus dan hasil dari makna sosial dalam konteks situasi tertentu. Konteks situasi, tempat teks itu terbentang, dipadatkan dalam teks, bukan dengan cara berangsur-angsur, bukan pula dengan cara mekanis yang ekstrim, tetapi melalui suatu hubungan yang sistematis antara lingkungan sosial di satu pihak, dengan organisasi bahasa yang berfungsi di lain pihak. Bahasa sebagai salah satu dari sejumlah sistem makna yang lain seperti tradisi, sistem mata pencarian, dan sistem sopan santun secara bersamasama membentuk budaya manusia. Halliday mencoba menghubungkan bahasa terutama dengan satu segi yang penting bagi pengalaman manusia, yakni segi struktur sosial.

Dalam pandangannya Halliday bahwa bahasa adalah produk proses sosial. Selanjutnya Halliday merumuskan "languageis a shared meaning potential, at once bohot a part of experience and anintersubjective interpretation of experience". Dalam komunikasi berdasarkan pengalaman yang dimilikinya yang bersifat intersubjektif itu masing-masing partisipan akan menafsirkan "teks" yang ada. Dengan demikian, makna akan selalu bersifat ganda.

Kajian yang muncul sebagai sebuah teks harus diinterpretasi dalam konteks ruang dan waktu itulah yang disentesisikannya dengan terminologi konteks situasi (context of situation) dan konteks budaya (context of culture). Fungsi konteks situasi,

\footnotetext{
${ }^{6}$ M.A.K Halliday, Bahasa, Konteks, dan Teks: Aspek-Aspek Bahasa dalam Pandangan semiotik Sosial. Terjemahan Barari (Jogyakarta: Gadjah Mada University, 1992), 4-5.

${ }^{7}$ M.A.K. Halliday dan Ruqiyah Hasan, Language, Context, and Text : Aspect of Language Interogatve In a Social Semiotic Perspective (Vivtoria: Deakin University, 1985), 4-5.

8 Anang Santosa, "Semiotik Sosial Halliday," Jurnal Bahasa dan Seni. no. 1 (2008):11 http://google.co.id. diakses tanggal 20 Januari 2013.

${ }^{9}$ Halliday, Bahasa, Konteks, dan Teks, 15.
} 
pengalaman, hubungan peran (role relation ships), juga dapat berperan sebagai alat symbol (symbolic channels) dalam pengungkapan makna teks.

Teori konteks situasi dan konteks budaya itu diterapkan dalam analisis teks mitos CRMT ini, karean teori konteks situasi dan budaya Halliday (1) memiliki tendensi untuk melihat bahasa sebagai fenomena sosial dan sistem tanda. ${ }^{10}$ (2) memiliki tendensi untuk menelaah bahasa dalam hubungannya dengan fungsi sosialnya. ${ }^{11}$ (3) Menelaah pemakaian bahasa dan sistem makna yang muncul akibat perubahan sosial.12

Berdasarkan fakta lingual yang dominan dalam teks mitos CRMT, maka kajian ini akan ditelaah dengan teori konteks situasi, konteks budaya, ${ }^{13}$ dan pendekatan teori semiotik sosial. ${ }^{14}$ Semiotik sosial untuk menganalisis fungsi dan makna mitos CRMT dalam konteks situasi dan konteks budaya.

\subsection{Konteks Situasi}

Halliday mengemukakan bahwa bahasa sebagai proses sosial tidak terlepas dari seperangkat makna dan teks. Makna menurutnya diproduksi dan direproduksi berdasarkan kondisi sosial tertentu, melalui agen dan objek-objek materi tertentu. Makna ada dalam hubungannya dengan subjek dan objek konkrit yang tidak bias diuraikan kecuali berdasarkan seperangkat hubungannya dengan struktur sosial. ${ }^{15}$ Masyarakat menurut Halliday selain diwujudkan dengan struktur sosial, juga diwujudkan melalui hubungan peran dan perilaku.Konteks situasi adalah lingkungan tempat berkembangnya teks. Konteks situasi adalah keseluruhan lingkungan, baik lingkungan tutur (verbal) maupun lingkungan tempat teks itu diproduksi (diucapkan atau ditulis). Untuk memahami teks dengan sebaik-baiknya, diperlukan pemahaman terhadap konteks situasi dan konteks budayanya. Halliday berpandangan bahwa konteks situasi melibatkan kajian tentang (1) medan wacana (field), (2) pelibat wacana (tenor), dan cara wacana (mode). ${ }^{16}$

\subsection{Konteks Budaya}

Konteks budaya dalam konteks sosial dan masyarakat merupakan hal yang intrinsik dalam semiotik. ${ }^{17}$ Fungsi konteks budaya sangat menentukan dalam menelaah sebuah wacana. ${ }^{18}$ Hal yang melandasinya: Pertama, Konteks semiotik diorganisasi sebagai suatu rangkaian teks dengan makna yang melekat pada kategori partisipan dan hubungannya. Kedua, Dalam semiotik, partisipan pesan dengan sejumlah kode menyangkut status pertukaran dan peran masing-masingnya. Ketiga, Semiotik melibatkan kontak langsung dengan partisipan, pembuat tanda cenderung mengikutsertakan instruksi dan konteks. Keempat, Seperangkat pesan yang mengorganisasi pertukaran semiotik tertentu akan mengimplikasikan model hubungan sosial.

\footnotetext{
10 M.A.K. Halliday, Language as Social Semiotic: The Social Interpretation of Language and Meaning (London: Edward Arnold, 1978), 106,123,126.

11 Ibid., 109.

12 Ibid., 106,114.

13 Ibid.

14 Ibid., 1985.

15 Ibid., 113.

16 Ibid., 110.

17 Ibid., 122-123, 125.

18 Ibid., 109, 124.
} 


\section{Interpretasi Cerita To Sala' Dadi}

2.1 Kajian Antropologi Sastra

Pokok-pokok bahasan yang ditawarkan dalam pendekatan CRMT adalah bagaimana menggunakan data dalam karya sastra, sebagai struktur naratif, di antaranya:

Aspek-aspek naratif karya sastra dari kebudayaan yang berbeda-beda. Penelitian aspek naratif sejak epic yang paling awal hingga novel yang paling modern. Bentuk-bentuk arkhais dalam karya sastra, baik dalam konteks karya individual maupun generasi. Bentuk-bentuk mitos dan sistem religi dalam karya sastra. Pengaruh mitos, sistem religi, dan citra primordial yang lain dalam kebudayaan populer.

Endraswara menjelaskan karya sastra selain mengandung data sosiologis, sekaligus mengandung data antropologis. Data sosiologis dan antropologis dalam karya sastra saling bersinggungan, tidak dapat dipisahkan satu dengan lainnya. Antropologi sastra tidak hanya terhubung dengan psikologi sastra melainkan juga dengan sosiologi sastra. Jika sosiologi sastra menitikberatkan karya satra sebagai refleksi kehidupan masyarakat dalam inetraksinya, anrtopologi sastra ke arah kajian etnogarfi dalam karya sastra. ${ }^{19}$

Selanjutnya Endraswara mengemukakan bahwa, analisis antropologi sastra semestinya akan mengungkap berbagai hal, antara lain: Kebiasaan-kebiasaan masa lampau yang berulang-ulang masih dilakukan dalam sebuah cipta sastra, seperti: semedi, melantunkan pantun, mengucapkan mantra-mantra, dan sejenisnya menjadi fokus penelitian;

Peneliti akan mengungkap akar tradisi atau subkultur serta kepercayaan seorang seorang penulis yang terpantul dalam karya sastra. Dalam kaitan ini tematema tradisional yang diwariskan turun temurun akan menjadi perhatian tersendiri;

Kajian juga dapat diarahkan pada aspek penikmat sastra etnografis, mengapa mereka sangat taat menjalankan pesan-pesan yang ada dalam karya sastra; Peneliti juga perlu memperhatikan bagaimana proses pewarisan tradisional dari waktu ke waktu; Kajian diarahkan pada unsur-unsur etnografis atau budaya masyarakat yang mengitari karya satra tersebut; Perlu dilakukan kajian terhadap simbol-simbol mitologi dan pola pikir masyarakat pengagumnya.

Antropologi sastra lisan termasuk juga ke dalam pendekatan arketipal, yaitu kajian karya sastra yang menekankan pada warisan budaya masa lalu. Warisan budaya tersebut dapat terpantul dalam karya-karya sastra klasik dan modern. Oleh karena itu, peneliti antropologi sastra dapat mengkaji keduanya dalam bentuk paparan etnografi. ${ }^{20} \mathrm{Hal}$ tersebut berhubungan dengan unsur-unsur mitos, legenda, dongeng, fantasi, dan sejarah dalam karya sastra. Satu lagi yang menjadi inti pendekatan ini ialah penelitian terhadap konsep kesadaran kolektif dan primordial images yang terungkap dalam karya sastra. Dalam pengaplikasiannya seseorang dituntut menguasai sistem dan budaya masyarakat. Fungsi antropologi sastra sama halnya dengan sosiologi dan psikologi sastra, yaitu untuk memperkenalkan kekayaan khazanah kultular bangsa sehingga masing-masing budaya menjadi milik bagi yang lain. Budaya cenderung ke arah penafsiran. Penafsiran budaya cenderung memandang fenomena budaya sebagai sebuah teks. Teks tersebut dapat ditafsirkan oleh pembaca itu sendiri.

19 Suwardi Endraswara, Metode Penelitian Sastra, Epistomologi, Model, Teori dan Aplikasi (Yogyakarta: CAPS, 2003), 109.

20 Ibid., 109. 
Sehubungan dengan hal itu, Ratna mengemukakan bahwa antropologi sastra sebagai analisis interdisipliner terakhir di satu pihak, rekaman keragaman kebudayaan Nusantara di pihak lain, maka peranan antropologi sastra sangat besar, sangat menentukan. ${ }^{21}$ Melalui kemampuan wacana, teks menurut pemahaman lain, karya sastra, baik lama maupun modern, baik lisan maupun tertulis menampilkannya demikian rupa, sebagai kreativitas imajinasi, sehingga pembaca memahaminya secara berbeda.

Menurut Bernard penelitian antropologi sastra lebih bersumber pada tiga hal yaitu: (a) manusia/orang, (b) artikel tentang sastra, (c) bibliografi). ${ }^{22}$ Ketiga sumber ini dapat dijadikan pijakan seorang peneliti untuk mengungkap makna di balik karya sastra. Ketiga sumber tersebut dipandang sebagai documentation resources. Hal ini memang patut dipahami karena karya sastra sebenarnya juga memiliki sumber informasi.

Kekhasan pendekatan antropologis sastra lisan adalah karya sastra meskipun hasil imajinasi, justru di dalam imajinasi itu nilai-nilai antropologis 'dipermainmainkan', di situlah lokus penelitian antropologi sastra ${ }^{23}$ Banyak hal dalam karya sastra yang memuat aspek-aspek etnografi kehidupan manusia dan sebaliknya tidak sedikit karya etnografi yang memuat kiasan-kiasan sastra. Jadi, penelitian sastra dapat menitikberatkan pada dua hal. Pertama, meneliti tulisan-tulisan etnografi yang berbau sastra untuk melihat estetikanya. Kedua, meneliti karya sastra dari sisi pandang etnografi, yaitu untuk melihat aspek-aspek budaya masyarakat.

Berdasarkan pandangan-pandangan di atas, maka mitos CRMT merupakan salah satu warisan budaya masa lalu, dan di dalamnya banyak mengandung ciri-ciri antropologis, sehingga sangat tepat digunakan pendekatan antropologi sastra.

\subsection{Struktur Cerita Tallu To Sala' Dadi}

Pada suatu hari di suatu tempat bertemulah tiga orang, masing-masing seorang buta, seorang lumpuh, dan seorang tuli. Dalam pertemuan ini mereka masing-masing mengemukkan pendapatnya dalam menghadapi kehidupan ini ditinjau dari situasi mereka masing-masing.

Terakhir orang tuli berkata "Lebih baik, kita pergi dari sini daripada tinggal duduk saja, tidak menghasilkan suatu apapun yang dapat digunakan untuk melanjutkan hidup kita." Mereka bertiga pergilah bersama-sama mengembara ke mana saja. Tiada berapa lama orang lumpuh itu melihat cangkul lalu dibawanya pergi. Dalam perjalanan selanjutnya mereka mengumpulkan kumbang gajah yang mengelilingi mereka sambil berbunyi-bunyi. Bunyi binatang itu di dengar oleh si Buta, tetapi ia tidak dapat menangkapnya karena ia tidak dapat melihatnya. Lalu disuruhlah si Tuli menangkapnya karena ia dapat melihat dan dapat pula berjalan untuk mengejarnya. Dalam perjalanan itu mereka menemukan lagi bulu ijuk dan gendang. Semua benda ini mereka bawa karena prinsip bahwa benda-benda itu merupakan rejeki bagi mereka. Makin lama makin jauh mereka berjalan, akhirnya tibalah di tengah hutan yang lebat. Di tengah hutan itu ada sebuah rumah. Rupanya

21 I Nyoman Kutha Ratna, Antropologi Sastra, Peranan Unsur-unsur Kebudayaan dalam Proses Kreatif. (Yogyakarta: Pustaka Pelajar, 2011), 440.

22 Russel H. Bernard, "The Literature Research" dalam Research Method in Anthropology (London-New Delhi: Sagé Publication, 1994), 118-120.

${ }^{23}$ I Nyoman Kutha Ratna,Teori, Metode, dan Teknik Penelitian Sastra (Yogyakarta: Pustaka Pelajar, 2004), 352. 
penghuni rumah itu adalah manusia hutan yang suka makan sesamanya. Di rumah ini banyak sekali harta yang dirampas dari orang yang sudah dimakannya.

Si Lumpuhlah yang meiihat rumah ini dan tahu bahwa penghuninya sedang bepergian. Bergegas-gegaslah mereka naik beserta benda-benda yang ditemukan di jalan tadi. Ketika mereka tiba di atas rumah, pintu dan jendela mereka tutup rapatrapat.

Tiada berapa lama, yang empunya rumah itu datang dan meiihat tanda-tanda bahwa sudah ada penghuni baru di atas rumahnya. Manusia hutan ini langsung menegur dengan menyuruh membuka pintu. Akan tetapi, dari atas rumah ia menerima jawaban, "Tidak boleh, ketahuilah aku ini manusia raksasa yang paling besar di dalam dunia." Manusia hutan ini tidak percaya sehingga ia ingin bukti dengan meminta supaya orang itu memperlihatkan sebuah giginya. Orang lumpuh segeralah memperlihatkan cangkul ke bawah kolong rumah. Selanjutnya, disuruh lagi memperlihatkan rambutnya. Dia menurunkan lagi bulu ijuk yang didapatkan dalam perjalanan tadi. Orang hutan ini mulai takut dan bimbang memikirkan bahwa benar manusia raksasa yang berada di atas rumahnya sekarang. Kemudian, disusul lagi dengan menjatuhkan kumbang gajah yang didapatkan di jalan tadi dan ia pun menjelaskan bahwa kumbang itu adalah kutunya. Meiihat semua itu manusia hutan makin ketakutan. Terakhir manusia hutan ini minta supaya orang itu memperdengarkan suaranya. Lalu si Buta di atas rumah memukul gendang dengan keras sehingga manusia hutan tadi terkejut lalu kepalanya terbentur ke tiang rumah dan akhirnya mati.

Mereka bertiga bergegas-gegas mengumpulkan harta dalam rumah orang hutan itu lalu segera pergi jauh dari tempat itu. Mereka membagi-bagi harta itu dan yang menjadi tukang bagi ialah si Tuli. Si Tuli mulai membagi dan menyebut satu per satu, "Ini bagian si Buta, ini bagian si Lumptih, ini bagian si Tuli, dan ini bagian orang yang membagi." Mendengar cara pembagian ini, si Buta berkata, "Kita hanya tiga orang saja yang akan mendapat bagian barang itu, mengapa sudah menjadi empat bagian." Si Tuli mengulangi lagi caranya membagi, "Bagian si Tuli, bagian si Buta, bagian si Lumpuh dan bagian orang yang membagi."

Si Buta mulai naik pitam dan marah lalu dia mengambil gagang cangkul yang didapatkan di jalan tadi kemudian memukul dengan membabi buta, tetapi yang sempat kena sasaran adalah yang tidak kuat lari. Secara kebetulan gagang cangkul yang dipukulkan oleh si Buta mengenai. lutut si Lumpuh sehingga ia sembuh dan dapat berjalan dengan baik. Karena si Lumpuh marah, ia mencakar muka si Buta sehingga ia melek dan penglihatannya menjadi terang. Selanjutnya si Buta mengambil lagi gagang cangkul kemudian memukul sekeliiing tulang pelipis si Tuli dan pada akhirnya menyebabkan si Tuli menjadi terang pendengarannya. Jadi, pada akhirnya orang yang buta dicakar matanya lalu melek (dapat melihat), orang lumpuh dipukul lututnya lalu dapat berjalan kembali, dan orang tuli dipukul bagian pelipisnya lalu menjadi normal kembali seperti biasa.

Setelah selesai kejadian itu mereka bertiga tertawa terbahak-bahak, kemudian membagi rata kembali harta yang mereka dapatkan. Demikianlah akhir cerita ini.

CRMT tallu to sala' dadi termasuk novel, yaitu cerita yang mengungkapkan pergumulan hidup manusia dalam menjalani kehidupan sehari-hari. Jika disinopsikan kembali runtutnya menjadi, (1) Orang buta, orang lumpuh, dan orang tuli bertemu di suatu tempat, lalu mereka saling memberikan pandangan masing-masing. (2) Mereka pergi mengembara ke tengah hutan. Dalam perjalanan,mereka menemukan bendabenda seperti cangkul, bulu ijuk, gendang dan kumbang gajah. Benda-benda itu 
dibawa ke mana saja mereka pergi. (3) Mereka tiba di rumah orang utan yang pada wakti itu sedang dalam keadaan kosong. Orang utan itu suka makan manusia. (4) Orang utan pulang ke rumahnya lalu ia bertanya kepada orang yangberada di atas rumah. (5) Orang cacat yang ada di atas rumah itu mengaku sebagai raksasa lalu memperlihatkan benda-benda yang ditemukannya dalam perjalanan. (6) Orang utan itu lari ketakutan sehingga kepalanya terbentur tiang rumah lalu ia mati. (7) Mereka membagi-bagi harta orang utan itu dengan cara yang tidak adil sehingga terjadi perkelahian di antara mereka. (8) Si Buta memukul lutut si Lumpuh, tiba-tiba si Lumpuh dapat berjalan;

si Lumpuh mencakar muka si Buta, tiba-tiba si Buta dapat melihat; kemudian si Buta memukul tulang pelipis si Tuli, tiba-tiba, si Tuli dapat mendengar.

Alur cerita yang dapat dituliskan kembali sebagai berikut. Tiga orang cacat pergi mengembara untuk mendapatkan perbaikan nasib mereka. Selama dalam perjalanan, mereka melaksanakan kerja sama yang baik menurut kodrat dan kemampuan masing-masing. Ditengah hutan, mereka menemukan rumah orang utan yang pada waktu itu dalam keadaan kosong. Ketika orang utan itu tiba di rumahnya, ia ditakut-takuti oleh ketiga orang cacat itu. Orang utan itu lari ketakutan sehingga tertumbuk di tiang rumah lalu ia mati. Ketiga orang cacat itu bersepakat membagi harta orang utan itu. Akan tetapi, karena kesalahan dalam membagi-bagi harta itu, maka timbullah perkelahian di antara mereka. Mereka bersyukur karena perkelahian itu menyebabkan mereka memperoleh bentuk fisik yang normal kembali; si Lumpuh menjadi kuat berjalan; si Buta menjadi dapat melihat; dan si Tuli menjadi dapat mendengar.

Alur ini menggambarkan kerja sama yang baik antara ketiga orang cacat dan berakhir dengan kebahagiaan. Peristiwa dimulai pada waktu mereka mendapatkan benda-benda dalam perjalanan kemudian berhasil membunuh orang utan lalu membagi-bagi hartanya, dan mencapai puncaknya ketika terjadi perkelahian yang berakhir dengan kebahagiaan.

Dalam cerita jni, tergambar adanya persamaan sifat yang dimiliki serta persamaan nasib yang dialami oleh ketiga orang cacat itu. Cangkul, gendang, bulu ijuk, kumbang gajah, adalah benda-benda yang digunakan untuk menakut-nakuti.

\subsection{Nilai Toleransi dalam Cerita Tallu To Sala' Dadi}

Perspektif citraan CRMT tallu to sala' dadi secara penokohan terbagi menjadi dua, humanis yaitu si buta, tuli dan lumpuh dan yang bukan humanis yaitu orang utan. Karakter humanis sendiri menggambarkan kehidupan manusia yang tidak sempurna. Dapat diinterpretasikan si buta sebagai karakter yang memiliki kekurangan dalam menilai dengan penglihatannya, si tuli memiliki kekurangan menilai segala sesuatu yang dia dengar, dan si lumpuh sebagai orang dengan karakter tidak dapat melangkahkan kaki ke tujuan. Keseluruhan karekter humanis ini tidaklah mungkin dapat melakukan sesuatu apapun tanpa mereka bekerja sama. Hal ini menjadi logika dasar CRMT tallu to sala' dadi yaitu tujuan barulah mungkin tercapai jika kita bekerjasama mengatasi kekurangan untuk suatu tujuan.

Jika dibandikan dengan tokoh 'orang utan' maka diperoleh interpretasi karekter yang menjadi lawan dari tallu to sala' dadi yaitu keserakahan, ketamakan, pertentangan, mampu melihat, mendengar, dan berjalan tetapi berperan sebagai penghancur. Karakter antagonis ini ialah simbol perlawanan dari unsur kesepahaman, kerjasama, dan demokrasi itu sendiri sebagaimana yang tergambar dalam karakter tallu to sala' dadi. 
Analisis selanjutnya berkaitan dengan nilai keberterimaan dan kesepahaman (acceptability and understanding) dalam CRMT. Pada alur pertama dari tallu to sala' dadi dikemukakan bahwa mereka berdialog bersama dan saling memahami untuk suatu tujuan. Sebagaimana data di bawah ini.

Pada suatu hari di suatu tempat bertemulah tiga orang, masing-masing seorang buta, seorang lumpuh, dan seorang tuli. Dalam pertemuan ini mereka masing-masing mengemukkan pendapatnya dalam menghadapi kehidupan ini ditinjau dari situasi mereka masing-masing.

Pada data di atas, ketiga orang cacat tersebut mengetahui bahwa mereka memiliki kelemahan masing-masing. Akan tetapi mereka dapat saling bertukar ide dan memberi pendapat hingga menemukan jalan keluar. Konteks yang dapat dikembangkan yaitu, nilai toleransi harus dipahami sebagai sebuah kondisi bukan berdasarkan kelebihan dan sikap memikirkan diri sendiri, tetapi dari kekurangan hingga tercapai kesepahaman. Konsep yang berkembang dari CRMT tallu to sala' dadi memberikan kepada kita ruang intpretasi bahwa keharmonisan dimulai dari sikap menyadari akan kekurangan. Karena pada prinsipnya tidak ada suatu konsep diri atau sosial yang benar-benar sempurna dan baik untuk menjadi dasar bagi keseluruhan kehidupan global. Setiap bangsa dapat terdiri dari berbagai budaya yang membangun sistem-sistem budayanya untuk berhadap-hadapan dengan lingkungan. Proses ini bergeser pada era globalisasi, yaitu bangsa-bangsa berhadapan dengan perkembangan global. Sehingga CRMT tallu to sala' dadi, memberikan world view mengenai toleransi harus didasarkan pada sikap keberterimaan dan kesepahaman.

Kesamaan konsep di era globalisasi ini justru muncul dari sikap humanis yang menyadari kelemahan diri. Kehidupan individu menjadi kehidupan sosial dalam tatanan yang luas. Peran pranata sosial akan bergerak dalam register yang lebih luas dimana sikap keberterimaan dan kesepahaman diperlukan untuk dapat membangun masyarakat global yang tangguh. Pesan untuk hidup dalam sikap keberterimaan dan kesepahaman sudah ditawarkan oleh masyarakat Toraja, bahkan jauh sebelum era globalisasi terlaksana.

Lebih lanjut, nilai toleransi yang tergambar dalam CRMT tallu to sala' dadi ialah kebersamaan (togetherness). Cerita rakyat ini memang sebuah cerita sederhana tetapi syarat akan nilai yang tergambar jelas dari alur ceritannya. Sebagaimana data penelitian yang dipaparkan di bawah ini.

Terakhir orang tuli berkata "Lebih baik, kita pergi dari sini daripada tinggal duduk saja, tidak menghasilkan suatu apapun yang dapat digunakan untuk melanjutkan hidup kita." Mereka bertiga pergilah bersama-sama mengembara ke mana saja. Tiada berapa lama orang lumpuh itu melihat cangkul lalu dibawanya pergi. Dalam perjalanan selanjutnya mereka mengumpulkan kumbang gajah yang mengelilingi mereka sambil berbunyi-bunyi. Bunyi binatang itu di dengar oleh si Buta, tetapi ia tidak dapat menangkapnya karena ia tidak dapat melihatnya. Lalu disuruhlah si Tuli menangkapnya karena ia dapat melihat dan dapat pula berjalan untuk mengejarnya. Dalam perjalanan itu mereka menemukan lagi bulu ijuk dan gendang. Semua benda ini mereka bawa karena prinsip bahwa bendabenda itu merupakan rejeki bagi mereka. Makin lama makin jauh mereka berjalan, akhirnya tibalah di tengah hutan yang lebat. Di tengah hutan itu ada sebuah rumah. Rupanya penghuni rumah itu adalah manusia hutan yang suka makan sesamanya. Di rumah ini banyak sekali harta yang dirampas dari orang yang sudah dimakannya.

Sikap kebersamaan dalam CRMT tallu to sala' dadi tidaklah terlepas dari sikap saling melengkapi (complementary), yaitu karakter si buta menjadi telinga dari si tuli, 
dan si tuli mejadi mata dari si buta, demikian halnya si buta dan dan si tuli menjadi kaki bagi si lumpuh dan si lumpuh melengkapi ketiganya.

Sikap kebersamaan dan saling melengkapi, merupakan point utama dalam keseluruhan alur CRMT tallu to sala' dadi. Representasi ini menjadi rujukan yang penting dalam kedinamisan struktur sosial. Masalah-masalah ekonomi, pendidikan, dan sosial seringkali masih terkendala dalam konseptualnya. CRMT tallu to sala' dadi memberikan konsep alternatif yang sederhana untuk mengatasi kendala tersebut.

Jika diterapkan pada alur cerita sebelumnya, maka akan diperoleh gambaran interpretasi karakter dan sikap. Kedua bagian ini sudah dapat memberikan gambaran tentang bagaimana konsep toleransi pada CRMT tallu to sala' dadi. Toleransi dikonsepkan sebagai sikap kebersamaan dan saling melengkapi dalam menghadapi tantangan intoleransi. Konsep intoleransi sendiri dalam bagian ini dapat disimbolkan dengan karakter orang utan. Sebagaimana dijelaskan pada bagian terdahulu. Dua sikap ini selalu bertolak belakang dalam setiap konteks sosial. Sehingga jika toleransi mewakili konsep keberterimaan, kesepahaman, kebersamaan dan saling melengkapi, maka sikap intoleransi sebaliknya.

CRMT tallu to sala' dadi, pada bagian akhir juga menjelaskan sebuah situasi yaitu konflik internal antara, si buta, tuli dan lumpuh. Konflik tersebut dijelasakan sebagaimana data di bawah ini.

Mereka bertiga bergegas-gegas mengumpulkan harta dalam rumah orang hutan itu lalu segera pergi jauh dari tempat itu. Mereka membagi-bagi harta itu dan yang menjadi tukang bagi ialah si Tuli. Si Tuli mulai membagi dan menyebut satu per satu, "Ini bagian si Buta, ini bagian si Lumptih, ini bagian si Tuli, dan ini bagian orang yang membagi." Mendengar cara pembagian ini, si Buta berkata, "Kita hanya tiga orang saja yang akan mendapat bagian barang itu, mengapa sudah menjadi empat bagian." Si Tuli mengulangi lagi caranya membagi, "Bagian si Tuli, bagian si Buta, bagian si Lumpuh dan bagian orang yang membagi."

Si Buta mulai naik pitam dan marah lalu dia mengambil gagang cangkul yang didapatkan di jalan tadi kemudian memukul dengan membabi buta, tetapi yang sempat kena sasaran adalah yang tidak kuat lari. Secara kebetulan gagang cangkul yang dipukulkan oleh si Buta mengenai. lutut si Lumpuh sehingga ia sembuh dan dapat berjalan dengan baik. Karena si Lumpuh marah, ia mencakar muka si Buta sehingga ia melek dan penglihatannya menjadi terang. Selanjutnya si Buta mengambil lagi gagang cangkul kemudian memukul sekeliiing tulang pelipis si Tuli dan pada akhirnya menyebabkan si Tuli menjadi terang pendengarannya. Jadi, pada akhirnya orang yang buta dicakar matanya lalu melek (dapat melihat), orang lumpuh dipukul lututnya lalu dapat berjalan kembali, dan orang tuli dipukul bagian pelipisnya lalu menjadi normal kembali seperti biasa.

Sebuah konflik sebagaimana dalam CRMT tallu to sala' dadi tidaklah selalu dipandang buruk. Karena dari sebuah konflik terjadi narasi dialogis yang justru menyelesaikan masalah utama utama dalam CRMT tallu to sala' dadi. Bagian ini memberikan banyak informasi dan sudut tafsiran yang terkait erat dengan antropologis sastra lisan itu sendiri. Alur cerita maju yang dikembangkan dari awal cerita seolah menimbulkan pertanyaan apa yang dilakukan ketiga orang cacat setelah mereka sembuh kecacatannya dan membagikan harta. Bagian ini diperlukan sebuah konsep yang dapat menyatukannya.

Analisa mendalam memberikan jawaban bahwa tantangan dan konflik internal pasti akan terus ada sekalipun ke tiga orang cacat tersebut telah kembali normal. Jika mungkin dibayangkan, maka jawaban yang paling logis ialah tantangan dan konflik internal yang lebih besar harus mereka hadapi setelah manjadi manusia normal kembali. Konsep pemikiran ini jika ditempatkan pada konteks sosial memiliki 
arti yang sangat mendalam yaitu falsafah hidup masyarakat Toraja yang memandang kepedihan dan kesedihan sebagai bagian yang harus diselesaikan bersama secara dialogis, serta-merta pula tantangan dari luar harus dihadapi. Ketika semuanya terlewati maka akan ada kembali tantangan, kepedihan dan kesedihan untuk itulah nilai keberterimaan dan kesepahaman dipadankan dengan kebersamaan dan saling melengkapi harus terus dijaga hingga tataran ideologis (adicitra).

Toleransi sebagai sebuah paradigma berada dalam posisi penting di tengahtengah tantangan dan konflik internal. Sehingga dapat disimpulkan bahwa konsep toleransi tidak hanya berkaitan dengan masalah agama, tetapi keseluruhan aspek kehidupan. Toleransi dalam CRMT tallu to sala' dadi tidak juga sebagai sikap individu semata, tetapi sikap sosial sebuah masyarakat, pandagan dunia dalam menghadapi konflik internal dan tantangan dari luar. Dengan demikian, keseluruhan pembahasan jika digambarkan dalam satu skema akan terlihat sebagaimana gambar di bawah ini.

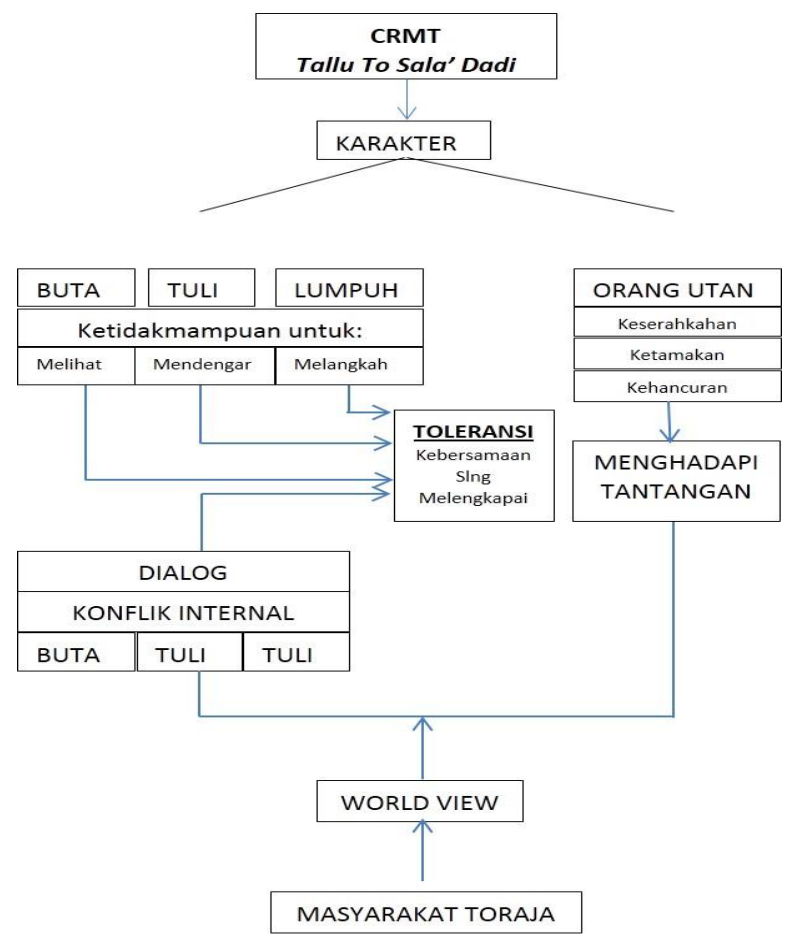

\section{KESIMPULAN}

Berdasarkan pemaparan di atas, dapat disimpulkan: Pertama, CRMT tallu to sala' dadi termasuk novel, yaitu cerita yang mengungkapkan pergumulan hidup manusia dalam menjalani kehidupan sehari-hari. Alur ini menggambarkan kerja sama yang baik antara ketiga orang cacat dan berakhir dengan kebahagiaan. Kedua, Nilainilai toleransi dalam CRMT tallu to sala' dadi meliputi nilai keberterimaan dan kesepahaman (acceptability and understanding) dipadankan dengan kebersamaan (togetherness) dan saling melengkapi (complementary). Jadi toleransi menurut CRMT tallu to sala' dadi adalah sikap menerima (acceptability) dan memahami (understanding) kekurangan dan perbedaan melalui kebersamaan dan saling melengkapi untuk menghadapi tantangan (global) dan memperbaiki kekurangan diri sendiri. 


\section{Daftar Pustaka}

Bernard, Russel H. "The Literature Research" dalam Research Method in Anthropology, London-New Delhi: Sagé Publication, 1994.

Endraswara, Suwardi. Metode Penelitian Sastra, Epistomologi, Model, Teori, dan Aplikasi. Yogyakarta: CAPS, 2003.

Finegan, Ruth. Oral Tradition and Verbal Arts. London: Chapman and Hall, 1979.

Halliday, M.AK dan Ruqiyah Hasan. Language, Context, and Text : Aspect of Language Interogatve in a Social Semiotic Perspective. Vivtoria: Deakin University, 1985.

Halliday, M.A.K. Language as Social Semiotic: The Social Interpretation of Language and Meaning. London: Edward Arnold, 1978.

Ratna, I Nyoman Kutha. Teori, Metode, dan Teknik Penelitian Sastra. Yogyakarta: Pustaka Pelajar, 2004.

Ratna, I Nyoman Kutha. Antropologi Sastra, Peranan Unsur-unsur Kebudayaan dalam Proses Kreatif. Yogyakarta: Pustaka Pelajar, 2011.

Ricoeur, Paul. Hermeneutics and the Human Science: Essay on Language, Action, and Interpretation. Cambrigde: Cambridge University Press, 1981.

Santosa, Anang. "Semiotik Sosial Halliday," Jurnal Bahasa dan Seni. No I (2008). http://google.co.id. diakses tanggal 20 Januari 2013.

Sumaryono, E. Hermeneutik Sebuah Metode Filsafat. Yogyakarta: Kanisius. 1993. 